\title{
SEKULARISASI DAN ISLAMISASI ILMU PENGETAHUAN
}

\author{
Saude \\ STAIN Datokarama Palu, Jl. Diponegoro 23 Palu \\ e-mail: Saude-rks@yahoo.co.id
}

\begin{abstract}
Discourse on islamization of knowledge essentially emerges from the serious concern to the failure of modern sciences to "give welfare to humanity". The basic problem is rooted in the philosophical framework behind modern sciences that science is free-value in that science is purely for science itself regardless of its impacts to humanity and environment. This in turn paves a way to sciences to go further without any impediment, or even without any purpose except for science itself. As a result, nature and humanity are exploited on behalf of science. Therefore, it is necessary to restore science into its proper position. Islam as a religion, which gives serious concern to knowledge and science, has views of knowledge and sciences which are different from a secular concept of science. This paper will discuss this issue.
\end{abstract}

إن التفكير فى أسلمت العلوم بشكل أساسى ينبثق من التأسف على إخفاق العلوم

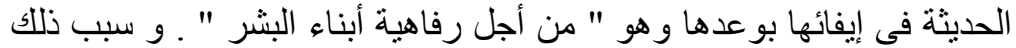

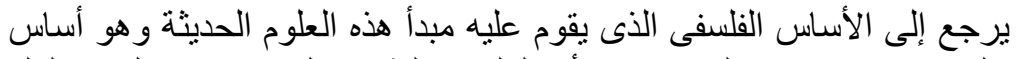

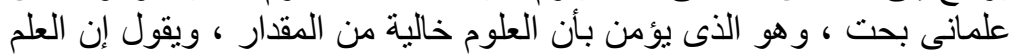

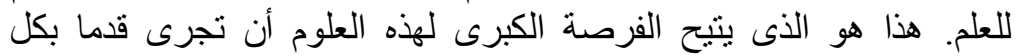

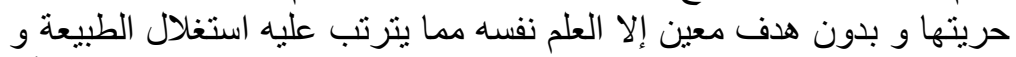

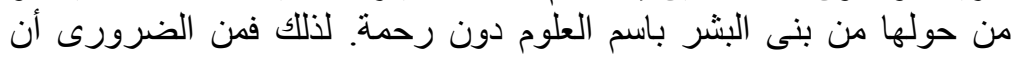

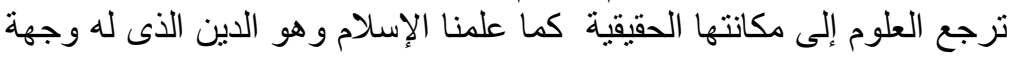
النطر المختلفة عن العلمانية

Kata Kunci : sekularisasi, islamisasi ilmu pengetahuan 


\section{PENDAHULUAN}

Perdebatan di sekitar wilayah keilmuan telah berlangsung sejak masa Islam klasik. Dua kubu yang berseteru dalam melihat validitas ilmu pengetahuan dalam Islam pada masa klasik ialah kubu filosof dan kubu ulama. Yang disebut pertama merupakan kelompok yang memandang semua ilmu itu berasal dari Tuhan, sedangkan kelompok kedua memandang bahwa hanya ilmu agama yang berasal dari Tuhan. Karena cara pandang inilah, lahirlah istilah ancient science dan revealed science.

Di era modern, istilah ancient science kemudian mengambil bentuk secular science. Kritik yang dilontarkan oleh para ulama terhadap ancient science ini diesebabkan oleh dasar epistemologi rasionalnya. Ketegangan ini mencapai puncaknya ketika terjadi polemik antara Ibn Rusd dan Al-Ghazâlî melalui karya Al-Ghazâlî,

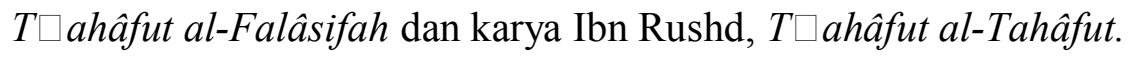

Perdebatan ini berlanjut di era modern, terutama ketika Barat berupaya mengkonstruksi sebuah epistemologi keilmuan yang dibangun di atas ide-ide sekularisme-rasionalisme. Sejarah mencatat bahwa sejak zaman pencerahan, tradisi ilmu pengetahuan modern ditandai oleh dua ciri; sekularisme dan meterialisme. Sekularisme membelah kebenaran dalam dua makna: kebenaran ilmiah dan kebenaran religius. Akibatnya, pandangan orang beragama pada realitas terbelah menjadi dua warna yang berbeda secara diametral (Mulyanto, 1991:55).

Karena diciptakan di masa pemerintahan kolonial, sistem pendidikan yang sekuler memegang porsi yang sangat besar dan mencampakkan sistem Islam dalam bidang ini. Dan perlu dicatat bahwa kolonialisme pada satu sisi melibatkan proses akulturasi terhadap nilai-nilai sekularisme itu sendiri (Tibi, 1994:24-29). Pendidikan Islam kebanyakan merupakan usaha swasta yang mendapat dana dari masyarakat. Apabila dana dari negara tersedia, maka desakan-desakan untuk sekularisasi dipaksakan dengan dalih demi modernisasi dan kemajuan. Desakan-desakan tersebut biasanya membagi dua kurikulum menjadi dua bagian yang berbeda (Al-Faruqi, 1982:11). 
Tulisan ini akan membahas dampak sekularisi terhadap ilmu pengetahuan dan upaya upaya untuk menanggulanginya melalui islamisasi pengetahuan.

\section{ISLAM DAN ILMU PENGETAHUAN}

Satu konsep yang paling jelas, komprehensif dan mendalam yang ditemukan di dalam Alquran adalah konsep ilmu. Tentu, dalam kedudukannya yang penting ini, ilmu hanya merupakan turunan dari tauhid (mengesakan) yang merupakan tema sentral dan konsep dasar Alquran. Sebagai bukti bahwa di dalam Alquran kedudukan ilmu sangat penting, Alquran menyinggung akar kata ilmu dan derivasinya sebanyak 800 kali. Ide tentang ilmu inilah yang membedakan pandangan dunia (worldview) Islam dengan semua paham dan ideologi dunia. Tidak ada pandangan lain yang dapat menyebabkan pencarian pengetahuan sebagai kewajiban individu dan kolektif serta memberikan tuntutan moral dan religius sebagai ibadah, selain pandangan Islam. Oleh karena itu, bagi Anes (dalam Sardar, 2000:3) ilmu menjadi ciri kebudayaan dan peradaban muslim.

Dalam sejarah perdaban muslim, konsep ilmu diresapi oleh semua lapisan masyarakat dan terimplementasikan di dalam seluruh kerja keras intelektual. Tidak ada peradaban lain dalam sejarah yang telah merangkul konsep "pengetahuan" dengan sedemikian erat dan mencarinya dengan sepenuh tenaga (Anes dalam Sardar, 2000:3).

Konsep Alquran mengenai 'ilm, yang biasanya diterjemahkan menjadi ilmu pengetahuan secara orisinil telah membentuk ciri-ciri utama peradaban muslim dan menuntunnya ke arah puncak kejayaannya. Waktu itu, sebagaimana halnya sekarang, ilmu telah menciptakan cara berpikir dan menyelidiki yang khas Islam. Ilmu membimbing bagaimana kaum muslimin memahami realitas dengan sebaik-baiknya, dan bagaimana pula membentuk dan mengembangkan suatu masyaratakat yang adil. Ilmu adalah perekat yang mengikat masyarakat muslim dengan lingkungannya sehingga memberikan bentuk yang dinamis dan hidup kepada Islam.

Kendatipun demikian, sementara sarjana-sarjana dan intelektualintelektual muslim klasik telah mengakui bahwa ilmu adalah konsep 
yang di dalamnya terdapat fondasi-fondasi pokok peradaban Muslim, dan bahwa ia merupakan sebuah nilai yang begitu pervasive. Sarjanasarjana kontemporer-baik yang modernis maupun yang tradisionalis - tampak mengesampingkan peranan kunci yang bisa dimainkan oleh epistemologi dalam membangun masyarakat.

\section{ILMU PENGETAHUAN DAN NESTAPA KEMANUSIAAN}

Ilmu pengetahuan yang berkembang di Barat telah memberikan kontribusi bagi penyingkapan rahasia-rahasia alam. Hal-hal yang pada awalnya dianggap mustahil bagi akal, kini dengan kasat mata dapat dibuktikan dengan perkembangan ilmu pengetahuan. Sumbangan ilmu pengetahuan di bidang kedokteran dapat dilihat melelui rekayasa genetika, bayi tabung dan cloning. Namun demikian, epistemologi sains modern juga telah memproduksi beberapa akibat yang dapat menyengsarakan.

Desakan untuk menolak pertimbangan nilai dalam rangka memperoleh ilmu pengetahuan menyebabkan sains memperlakukan objek penelitian (manusia maupun bukan manusia) sebagai benda mati yang dapat dieksploitasi, dimanipulasi, dibedah, bahkan disiksa - atas nama sains. Penekanannya yang menyeluruh pada penguasaan dan dominasi telah menghasilkan krisis ekologi yang telah megancam tempat kediaman manusia di bumi ini. Metodologinya telah mereduksi sains dalam proses tanpa akhir untuk memecahkan, membekukan atau mematirasakan seorang subyek ketika mempelajari; dan kemudian menempatkannya pada suatu jarak ketika mengevaluasi.

Dalam bentuknya yang lebih ekstrim, misalnya, dalam reduksionisme biologis, sains telah dirasuki oleh apa yang disebut Erich Fromm necrophilia, gairah membunuh. Bahwa sains secara tak terelakkan telah bergandengan dengan penindasan dan dominasi; bukanlah suatu kebetulan belaka; ia merupakan produk langsung dari epistemologi rasionalistik, sebagaimana Newton, Darwin, Freud, B.H. Skinner dan Edward Wilson adalah produk-produk dari epistemologi yang sama.

Dalam konteks di atas, Fazlur Rahman (1993) mengemukakan bahwa persoalan yang timbul sekarang ialah bagaimana manusia 
bertanggung jawab? Ini masalah mendasar yang kita maksudkan sebagai islamisasi ilmu pengetahuan. Kita merasakan bahwa dunia modern saat ini telah berkembang dan terbangun atas pengetahuan yang tak dapat dianggap islami. Yang kita maksud ialah bahwa dunia modern telah menyalahgunakan ilmu pengetahuan, sementara tidak ada masalah dengan ilmu pengetahuan.

Kita membutuhkan sains untuk pembangunan paradaban sebagai suatu sistem objektif untuk memecahkan masalah-masalah yang terkerangka sesuai dengan paradigmanya sendiri. Sains Islam harus muncul dari nilai-nilai dan konsep-konsep Islam yang abadi. Tanpa sains Islam, masyarakat muslim hanya akan menjadi bagian dari peradaban Barat (Sardar, 1998:59).

Sains Islam, tentu saja harus berangkat dari pandangan dunia yang Islami. Karena, semua nilai dan tindakan manusia, sadar atau tidak, merupakan refleksi atas keyakinan-keyakinan metafisis atau pandangan dunianya tertentu. Bidang pengetahuan dan pendidikan merupakan dua bidang yang secara organis berakar pada pandangan dunia itu, sebagaimana hal itu ditunjukkan oleh kajian filsafat dan sosiologi pengetahuan dan pendidikan. Pandangan dunia Islam dapat didefinisikan dalam dua tingkat. Tingkat pertama, adalah seluruh penafsiran manusia terhadap dunia, dan kedua adalah tentang kehidupan kita di dunia ini, yaitu seluruh nilai yang dengannya seseorang hidup, dan ini membentuk suatu problem etika (Wan Daud, 1989:10).

Di dalam Islam, lingkaran nilai-nilai dan konsep-konsep seperti tauhid, khalifah, akhirat, ibadah, ilm dan istislah, individu-individu dan masyarakat akan bebas mengekspreksikan individualitasnya dan memenuhi kebutuhan-kebutuhannya sesuai dengan apa yang mereka inginkan sejauh daerah yang telah diterangkan oleh nilai-nilai dan konsep-konsep abadi itu bisa dipetakan. Sepanjang sejarah Islam, kita dapat melihat bahwa berbagai masyarakat muslim telah memanifestasikan nilai-nilai tersebut melalui berbagai cara sesuai dengan kondisi sejarah dan lingkungan mereka. Dengan mekanisme seperti inilah, peradaban Islam senantiasa berubah. 
Pada kenyataannya, semangat ilmiah para ilmuwan dan sarjana muslim mengalir dari kesadaran mereka akan tauhid. Tak diragukan lagi, asal-usul dan perkembangan semangat ilmiah dalam Islam berbeda dengan asal-usul dan perkembangan hal yang sama di Barat. Orang-orang Islam mulai menaruh perhatian pada ilmu-ilmu alam secara serius pada abad ketiga Hijriah (abad kesembilan Masehi). Tetapi pada saat itu mereka telah memiliki sikap dan kerangka ilmiah yang diwarisi dari ilmu-ilmu agama. Semangat untuk mencari kebenaran dan objektivitas, penghormatan terhadap bukti empiris yang memiliki dasar yang kuat, serta analisis yang tajam dapat kita temukan dalam kajian-kajian jurisprudensi (fiqh) dan hadis Nabi (Bakar, 1991:12).

Masyarakat muslim kontemporer memiliki kebutuhan-kebutuhan dan kondisi khusus yang perlu disesuaikan dengan pandangan dunia Islam. Beberapa dari kebutuhan-kebutuhan itu, seperti sandangpangan berlaku sama bagi setiap orang. Namun kebutuhan-kebutuhan lainnya, seperti perlunya melepaskan ketergantungan dan eksploitasi teknologi, merupakan produk situasi sejarahnya yang khusus. Yang lainnya merupakan hasil dari kebudayaan muslim itu sendiri; tipe tempat tinggal yang cocok dengan way of life Islam.

Meski hampir sebagian besar hasil-hasil ilmu pengetahuan modern sesuai dengan pernyataan Aqluran, bahkan sebagian dari kita yang optimis dengan berani menyatakan bahwa pada dasarnya ilmu pengetahuan modern hanya akan memverifikasikan kandungan Alquran - namun umat tak dapat menutup mata bahwa "anak yang terlantar ini” harus dikembalikan kepada ibu kandungnya; ibu yang bijaksana untuk segera dibersihkan dari noda-noda sekularisme yang melekat kuat pada padannya.

Ilmu pengetahuan harus terbuka pada konteksnya, dan Islam kita itulah yang menjadi konteksnya, yang akan mengarahkan ilmu pengetahuan menuju tujuan hakikinya; yakni memahami realitas alam, untuk memahami eksistensi Allah, agar manusia menjadi sadar akan hakekat penciptaan dirinya, dan sama sekali bukan mengarahkan ilmu pengetahuan melulu pada praksis, pada kemudahan-kemudahan material duniawi. 
Dalam tradisi intelektual Islam, ada suatu hirarki dan kesalinghubungan antar-berbagai disiplin ilmu yang memungkinkan realisasi kesatuan (tauhid) dalam kemajemukan, bukan hanya dalam wilayah iman dan pengalaman keagamaan, tetapi juga dalam dunia ilmu pengetahuan. Kekacauan yang mewarnai kurikulum pendidikan modern di kebanyakan Negara Islam, menurut Nasr (dalam Bakar, 1998:11), dalam banyak hal disebabkan oleh hilangnya visi hirarkis pengetahuan seperti yang dijumpai dalam tradisi Islam klasik.

Konsep epistemologi dalam Islam pada hakekatnya tidak terlepas dari dimensi teologisnya yang bercorak tauhid. Dalam konsep epistemologi Islam ilmu pengetahuan dipandang sebagai perpanjangan dari ayat-ayat Allah dalam semua ciptaan-Nya (Asy'arie, 1999: 92). Di sinilah arti penting apa yang disebut dengan islamisasi ilmu pengatahuan, yakni mengembalikan ilmu pengetahuan kepada jalur yang semestinya, sehingga menjadi berkah dan rahmat kepada manusia dan alam, bukan malah sebaliknya membahwa mudarat.

\section{ISLAMISASI ILMU PENGETAHUAN}

Sebelum berbicara lebih lanjut mengenai islamisasi ilmu pengetahuan, ada baiknya ditampilkan suatu gejala dalam umat yang disebut dengan istilah Bucallisme. Gejala ini dalam batas-batas tertentu masih posistif bagi semangat penguasaan ilmu pengetahuan. Namun demikian, bilamana batas-batas ini terlampaui, maka bukan cuma semangat yang menjadi pupus, bahkan lebih jauh lagi yang terjadi adalah keterbuaian dan lupa pada tugas semula, yang justru akan menjadi kendala dalam upaya islamisasi ilmu pengetahuan. Gejala ini muncul karena kenyataan bahwa hasil-hasil ilmu pengetahuan modern, sebagaimana yang ditulis Maruice Bucaille, banyak kesesuain antara kitab suci Alquran. Untuk menjadikan reliatas ini sebagai penghibur atas kesalahan beruntun dam keterhinaan di lapangan ilmu pengetahuan, ditambah dengan kenangan manis dominasi ilmu pengetahuan sarjana-sarjana muslim masa lampau, maka lengkaplah gejala isolasi diri dengan lari ke alam kenangan masa lalu, tanpa berupaya memberi akses yang islami terhadap dunia modern saat ini. 
Dalam konteks inilah, sejarah masa lalu seharusnya dapat mengantar kepada suatu keyakinan bahwa umat mampu dan secara potensial berada pada garis terdepan dalam lapangan ilmu pengetahuan. Kesadaran diri membuat umat berani menatap masa kini dengan segala kesalahannya tanpa harus menyesal dan mengutuk alur sejarah. Kenangan ini seharusnya mengkristal dalam tekad "Umat mampu, kalau memang mau". Kondisi masa kini mengantarkan pada umat suatu keadaran bahwa kita harus "mau" mengambil peran yang telah diberikan Allah kepada kita sebagai pemimpin (khalifah) di segala lapangan kehidupan, termasuk lapangan ilmu pengetahuan. Bila tidak, maka kondisi masa kini tak akan bergerak pada arah yang merupakan tujuan umat, bahkan justru menjauhi tujuan islamisasi tersebut.

Berdasarkan kesadaran sejarah itulah, islamisasi ilmu pengetahuan, tidak lain dari proses pengembalian atau pemurnian ilmu pengetahuan pada prinsip-prinsip yang hakiki, yaitu tauhid, kesatuan makna kebenaran, dan kesatuan sumber ilmu pengetahuan. Dari ketiga prinsip, yang disebut prinsip dasar ilmu pengetahuan islami inilah, kemudian diturunkan aksiologi, epistemologi, dan ontologi ilmu pengetahuan. Untuk mencapai maksud tersebut, menurut Mulyanto (1991:34), ada tiga prinsip yang perlu diperhatikan:

Pertama, ilmu pengetahuan tidaklah diabadikan melulu pada praksis, tetapi dihambakan pada tujuan-tujuan memahami eksistensi hakiki alam dan manusia. Ilmu pengetahuan tidaklah berkembang pada arah yang tak terkendali, tetapi ia berkembang pada arah yang maknawi dan umat berkuasa untuk mengendaliknnya. Kekuasaan manusia atas ilmu pengetahuan harus mendapat tempat yang utuheksistensi ilmu pengetahuan bukan melulu untuk mendesak kemanusiaan, tetapi kekuasaanlah yang harus menggenggam ilmu pengetahuan untuk kepentingan dirinnya dalam rangka penghambaan diri pada Sang Pencipta Yang Agung. Ringkasnya, ilmu pengetahuan dikembangkan ke arah di mana dicapai secara terus-menerus pengertian yang lebih baik, bahwa Allah Yang Maha Esa-lah sumber dari segala sumber ilmu pengetahuan, yang dengan itu, ilmu pengetahuan mengantarkan umat kepada peningkatan keimanan. 
Mengabdikan ilmu pengetahuan pada tujuan-tujuan di atas, jelas akan dipandang oleh kaum scientistme sebagai pemasungan ilmu pengetahuan secara agamis. Oleh karena itu, umat harus siap menangkis tuduhan itu sebab tak ada pilihan lain bagi kita daripada menerima keadaan terlumurinya ilmu pengetahuan oleh paham sekularisme.

Kedua, membebaskan ilmu pengetahuan dari jeratan sekularisme. Dengan demikian, tak ada lagi istlah kebenaran ilmiah dan kebenaran religius. Yang ada hanyalah kebenaran tunggal, kebenaran ilmiah sekaligus kebenaran religius. Melalui prinsip ini, kompromi yang terus-menerus antara hasil-hasil ilmu dan hasil-hasil interpretasi manusia atas wahyu, menyatu dalam kebenaran tunggal yang tidak memberikan pertentangan. Interpretasi wahyu mengenai realitas, mendapat batu uji melalui hasil-hasil ilmu pengetahuan. Jadi, andai interpretasi manusia atas realitas beradasarkan wahyu itu benar, maka ia pun akan dibenarkan pernyataan ilmu pengetahuan; begitu pula sebaliknya, pernyataan-pernyataan yang muncul dari ilmu pengetahuan, akan mendapat batu uji dari wahyu, karena kita meyakini kebenaran tunggal yang datang dari Allah semata.

Ketiga, menjadikan Alquran sebagai sumber ilmu pengetahuan. Dengan demikian, kedua sumber ilmu pengetahuan, baik fenomena alam (ayat tak tertulis), maupun Alquran memiliki kedudukan yang sama. Prinsip ini menopang prinsip yang kedua karena ayat-ayat Allah selalu benar, tak akan ada kontrdiksi di antara keduanya (wahyu dan alam). Dan bilamana memang belum ada kesesuaian, maka kesalahan terletak pada manusia yang menginterpretasikan dan mendeskripsikan ayat-ayat itu sendiri.

Melalui pemahaman terhadap ketiga prinsip di atas, yang satu sama lain saling menopang, maka roda islamisasi pengetahuan digulirkan. Sekarang masalahnya, pada bagian ilmu pengetahuan yang mana proses ini dijalankan?

\section{OBJEK ISLAMISASI}

Dewasa ini, ilmu pengetahuan sudah mampu menguak hampir semua tirai misteri fenomena alam. Ilmu pengatahuan telah menjelajahi pelbagai bidang, menajamkan cabang-cabangnya dan memunculkan cabang baru. Ilmu pengetahuan dalam 
penghambaannya pada praksis atau pada dirinya sendiri (ilmu untuk ilmu) berkembang, menjadi ilmu pengetahuan terapan dan ilmu pengetahuan fundamental (murni).

Ilmu pengetahuan fundamental secara sepintas tampak tidak berguna bagi praksis dan hanya terlihat sebagai sarana kepuasan rohaniah para ilmuan belaka. Dengan kata lain, ilmu pengetahuan fundamental hanyalah dihambakan pada ilmu pengetahuan itu sendiri, terisiolasi dari kehidupan. Namun demikian, kalau dilihat lebih dalam, ada keterkaitan antara ilmu pengetahuan fundamental dengan praksis. Karena dari yang pertama itulah muncul konsep-konsep yang menjadi prinsip untuk bias diterapkan pada yang kedua, yang kemudian dikenal dengan teknologi.

Banyak yang beranggapan bahwa ilmu itu bebas nilai, tidak ada baik dan buruk. Kalaupun kemudian ilmu pengetahuan melahirkan hal-hal negatif, hal itu tidak lain karena penerapannya yang keliru, sehingga yang perlu diluruskan adalah pada tataran aplikasinya. Bila demikian halnya, pada sisi manakah islamisasi itu diperlukan? Apakah pada ilmu-ilmu fundamental teoritisnya, atau pada tataran aplikasi praktisnya? Sehingga yang diperlukan bukannya islamisasi ilmu pengetahuan tapi islamisasi teknologi?

Perlu ditegaskan, bahwa islamisasi ilmu pengetahuan bukanlah proyek tambal sulam dari apa yang dihasilkan oleh budaya sekuler. Islamisasi pengetahuan menghendaki perubahan radikal secara total, dan yang pertama dari semuanya adalah perubahan paradigma terhadap ilmu pengetahuan itu sendiri sejalan pandangan dunia Islam (tauhid). Menurut Sardar, seperti dikutip oleh Nashori (1995:116), islamisasi ilmu pengetahuan harus dimulai dengan membangun pandangan dunia (world view) Islam dengan titik utama membangun epistemologi Islam. Bila yang dilakukan hanya pada produk ilmu pengetahuan itu sendiri tanpa merubah pandangan dunia dan epistemologinya, bias jadi kita justru akan terjebak, yang terjadi bukannya islamisasi ilmu pengetahuan tetapi westernisasi Islam.

\section{PENUTUP}

Berdasarkan uraian sebelumnya, dapat disimpulkan bahwa sekularisasi ilmu pengetahuan di Barat telah menyebabkan terpisahnya tujuan pencarian ilmu pengetahuan sebagai basis terciptanya suatu 
masyarakat yang bermoral. Hal ini disebabkan oleh cara pandang sekuler bahwa tujuan ilmu adalah ilmu. Sedangkan bagi Islam, tujuan ilmu adalah penghambaan kepada Allah swt. dan merupakan implementasi dari prinsip tauhid. Dengan demikian, bagi Islam berilmu berarti beribadah dan bertujuan untuk menciptakan tatanan dunia yang humanis. Dalam konteks ini, Islam tidak sependapat pandangan dunia Barat yang secara bebas mengeksploitasi alam dan manusia demi ilmu pengetahuan, apalagi bilamana ilmu pengetahuan dimanfaatkan untuk memusnahkan umat manusia. Dengan demikian, pandangan dunia Barat yang sekuler tentang ilmu pengetahuan harus diislamkan. Dan langkah pertama untuk itu adalah dengan membangun world view dan epistemologi Islam.

\section{DAFTAR PUSTAKA}

Ancok, Jamaluddin \& Fuat Nashori Suroso. 1995. Psikologi Islami: Solusi Islam atas Problem-problem Psikologi. Cet. ke-2. Yogyakarta: Pustaka Pelajar.

Anees, Munawar Ahmad. 2000. Ilmu yang Mencerahkan. Dalam Ziauddin Sardar (Ed.), Merombak Pola Pikir Intelektual Muslim. Terjemahan oleh Agung Prihantoro dan Fuad Arif Fudyartanto. Yogyakarta: Pustaka Pelajar.

Asy'arie, Musa. 1999. Filsafat Islam tentang Kebudayaan. Yogyakarta: Lembaga Studi Filsafat Islam (LESFI).

Bakar, Osman. 1991. Tawhid and Science: Essays on the History and Philosophy of Islamic Science. Terjemahan oleh Yuliani Liputo. Bandung: Pustaka Hidayah.

- 1998. Classification of Knowledge in Islam: A Study in Islamic Philosophy of Science. Terjemahan oleh Purwanto. Bandung: Mizan.

al-Faruqi, Ismai'l Raji. 1982. Islamization of Knowledge: General Principles and Workplan. Terjemahan oleh Anas Mahyuddin. Bandung: Pustaka.

Mulyanto. 1991. Islamisasai Ilmu Pengetahuan. Ulumul Qur'an. XI.

Rahman, Fazlur. 1993. Islamisasi Ilmu Pengetahuan: Suatu Tanggapan. AlHikmah. Edisi Nopember-Desember.

Sardar, Ziauddin. 1998. Jihad Intelektual: Merumuskan Parameterparameter Sains Islam. AE. Priyono (Ed.) Cet. I. Surabaya: Risalah Gusti.

Tibi, Bassam. 1994. The Crisis of Modern Islam: A Preindustrial Culture in The Scientific Technological Age. Terjemahan oleh Yudian W. Asmin. Yogyakarta: Tiara Wacana Yogya. 
Jurnal Hunafa Vol. 5, No. 2, Agustus 2008: 165-176

Wan Daud, Wn Moch. Nur. 1989. The Concept of Knowledge in Islam and Its Implikation for Education in Developing Country. Terjemahan oleh Munir. Bandung: Pustaka. 